\title{
2006-247: THE IMPORTANCE OF HONORS SCHOLARS PROGRAMS IN ENGINEERING TECHNOLOGY EDUCATION
}

\section{George Suckarieh, University of Cincinnati}

Dr. George Suckarieh is a Full Professor of Construction Science at University of Cincinnati College of Applied Science. Dr. Suckarieh received a PhD in Civil Engineering and a Masters in Business Administration from Ohio State University. He directs/coordinates UC Honors Scholars Program at the college and is a member of the University Honors Council. He teaches courses in Construction Management and Productivity Improvement. Dr. Suckarieh is Professional Engineer in the State of Ohio, a member of the American Society of Civil Engineer, American Institute of Constructors. He serves as a council member in the City of Madeira Ohio.

\section{Kathleen Ossman, University of Cincinnati}

Dr. Kathleen Ossman is an assistant professor in the Electrical and Computer Engineering Technology Department at the University of Cincinnati. She received a BSEE and MSEE from Georgia Tech in 1982 and a Ph.D. from the University of Florida in 1986. Her interests include feedback control systems and digital signal processing. 


\title{
The Importance of Honors Scholars Programs in Engineering Technology Education
}

\begin{abstract}
This paper discusses the University Honors Scholars Program at College of Applied Science, University of Cincinnati. It presents the requirements for graduating from the program, and discusses how these requirements are used to enrich the educational experiences of honors technology students in the program as well as promoting faculty scholarship. It also presents a range of activities and research that involved honors students and faculty to promote the education of all engineering technology students.
\end{abstract}

\section{Introduction}

Undergraduate Honors Scholars Programs when well conceived, act as catalysts for improving educational processes and for motivating all students in engineering technology programs. In the absence of graduate education, honors programs provide opportunities to motivate students and faculty to promote rich educational environment through research and innovative teaching pedagogies.

College of Applied Science at University of Cincinnati has long suffered from the absence of graduate programs. As such, support for applied scientific research that enhance the knowledge objectives of the programs lagged behind. Enhancing cognitive objectives of the programs was limited to what faculty read in literatures, captured from conferences or assimilated from casual consulting that they conducted. The increase of administrative support to University Honors Scholars program in the college reversed this limitation. In the program, Honors students and faculty participated in scholarly activities and applied research. In addition, faculty collaborated in several educational communities that improved teaching pedagogies, resulted in real enriching experiences to faculty and students alike, and significantly contributed to the betterment of education of the students.

At College of Applied Science, faculty and students collaborations in the Honors program took on various forms. Collaborative applied research with industry, like the formation of knowledge base that captured the experience of company professionals, provided new opportunities for enhancing students' education. Faculty community "Problem Based Learning" enriched the cultural and educational experience of the students. Pilot programs like "Assessment with Portfolios" helped in developing formative and summative experiences of honors students and in verifying portfolios' usefulness for all the students in the college. These enriching experiences promoted the technology programs to a new level and partially filled the gap in learning and teaching created by lack of graduate programs. The sudden surge of participation of Honors 
students and faculty in Honors contracts, and the ensuing publications attest to the level of scholarship that takes place in the programs.

\section{University Honors Scholars Programs}

Honors programs have served universities nationwide to attract academically talented and motivated students who yearn to achieve their potential during their college experience. An honors program enriches the educational experience of top students through curricular and co-curricular opportunities. In most universities, honors students are invited to join honors communities that have special privileges. They receive scholarships and have access to special facilities such as honors residences and honors lounges equipped with modern computers and libraries with special checkout privileges to further their persistence in search of knowledge. In addition, honors classes have smaller number of students ${ }^{[1]}$.

At University of Cincinnati, Students are invited to join the University Honors Scholars Program (UHSP) based on high school qualifications. Typical qualifications of students who are admitted to the program include an ACT score of over 29, an SAT score of over 1300 (verbal and math combined), a class rank in the top $10 \%$, an un-weighted high school GPA of 3.7/4.0 scale. Transfer students from within the university are expected to have 3.4 cumulative GPA for at least two Quarters and a recommendation from a faculty member of the university. All students are required to write essays that demonstrate the students' leadership capacities, a willingness to take on challenges, and an interest in becoming engaged in local and global communities. The essays are carefully evaluated prior to admitting the students ${ }^{[1]}$.

University of Cincinnati Honors Scholars Program promotes five pillars of enriching experiences in Leadership, Global Studies, Community Engagement, Research and Creative Arts, and Interdisciplinary Studies. To graduate "With Honors" distinction, students must maintain 3.2 GPA and complete 36 Quarter credit hours of honors courses. These could include a combination credits of honors sections of requires classes, Honors Special Topics courses, courses contracted for honors, honors independent study courses, honors cooperative work experience, and up to six credit hours of high school transfer honors courses in two different disciplines ${ }^{[2]}$.

In Engineering Technology programs, due to sizes of the programs and original small classes, the combination of formal honors courses may not be available in sufficient numbers for the students to fulfill graduation requirements for "With Honors" distinction. Flexibility of the programs in providing enriching experiences to serve academically talented students becomes extremely important for the success of the programs. However, when well conceived, the programs become catalysts to all technology programs as they provide new dimensions to faculty and students. Not only technology honors programs enrich the education of honors students, but they also fill an important gap for professional development of faculty created by lack of funding and/or lack of graduate programs, and promote expansion of education in the undergraduate engineering technology curricula. 


\section{Honors Sections of Courses in the Programs}

Honors sections of required courses are usually possible when honors students are available in enough numbers to form special honors sections. In a large urban university, creating honors sections of large number of students is relatively uncomplicated. Honors sections of courses challenge the students and provide them with enriching experiences not available in other sections. Sometimes the difference is exhibited in the pedagogy of teaching where more research is emphasized, other times assignments are different from non-honors sections to challenge honors students to push the boundaries of their learning potential.

The following example demonstrates the enriching experience provided by Freshman English 101 course. For the last couple of years, 20 first-year Honors Scholars students from University of Cincinnati worked on the university's latest partnership with Habitat for Humanity as they connected to the community through a special section of Honors English 101. The course was designed around the university commitment to join Habitat for Humanity in building homes in neighborhoods close to campus. A group of 20 Honors English 101 freshman students worked at the site for two weeks just before the starting of the coursework. The students were guided by Upper level honors technology students in Construction Management and in Architectural Engineering Technology from College of Applied Science who earned experiential honors credits for the class.

After their experience and during the regular class, the students worked on assignments designed around three key themes:

- A reflection of how the experience has affected them personally

- A paper that focuses on working in partnership with the community

- A paper about sharing experiences with others in their community

The class helped the freshmen form friendships before school even begins. It helped in breaking down some of the apprehensions the students have with their professor in a way that they have not experienced in a classroom ${ }^{[3]}$.

The College of Applied Science is the college of technology at University of Cincinnati. Its campus is located at a short three miles from University main campus. Every year about two hundred freshmen are accepted into various technology programs. The number of entering freshmen that apply to the Honors Program from the onset is very small; it is usually less than ten students. As such, there are very little opportunities to create special honors sections for them. After the grades for the first Quarter are posted, faculty members in the program recruit freshmen students with a 3.4 or higher GPA. These students are invited to join the Honors program provided they obtain recommendation from a faculty member. As a result, the number of honors students typically increases to over fifteen students. In the Spring Quarter, the college offers one section of Honors English 103. 
Honors sections of required courses are not without significant cost to universities. In a large class, where one faculty delivers the course with the help of graduate assistants to several hundred students in the class, the cost could be substantial. However, in multiple sections of small classes like Freshman English classes, where the number of students in the class is in the twenties, the cost differential is not as high. The question becomes that of university commitment to the Honors program and that of balancing class sizes.

\section{Special Topics Courses}

Honors Special Topics courses add new dimensions to the programs. Special Topic courses cross the boundary of disciplines to provide the student with an enriching education with unique breadths. At University of Cincinnati, Honors Special Topics courses are designed for honors students of any discipline. Faculty members compete on offering honors courses by responding to a request of proposal. The requirements for Honors Special Topics courses are that they shall broaden the intellectual horizon of the students regardless of the disciplines in which students are majoring. The University Honors Scholars Program describes Honors Special Topics courses as "specialized courses for the non-specialist." [1]. Honors Special Topics courses, therefore, are not survey courses, do not normally require any prerequisites, and should provide a positive learning experience for students majoring in all disciplines. Proposals for Honors Special Topics courses can come from any discipline in any college at the University. Interdisciplinary courses are encouraged. Traditional Special Topics Courses have consisted of an in-depth treatment of a topic (rather than a surface-level overview). They have been taught from both disciplinary and interdisciplinary viewpoints.

Honors Special Topics courses focus on five themes: Interdisciplinary Studies, Leadership, Global Studies, Community Engagement, and Research and Creative Arts. They function like seminars, with faculty-student dialogue serving as the primary mode of interaction. Collaborative student work, experiential learning, innovative technology, problem-based learning, and primary course readings are also encouraged in order to take advantage of the class limit of 20-25 students. Special Topics courses are offered for three credit hours and should be accessible to a non-specialist ${ }^{[1]}$.

Faculty members in the College of Applied Science successfully responded to proposals and taught many Honors Special Topics courses. The goal of the College is to teach one course every Quarter. Faculty members of the college often use the Honors Special Topics courses as a springboard to improve their teaching pedagogy before applying it to other courses. In the course "Historical London in the Lens of Technology", seven faculty members from various technology programs, obtained an internal university grant to learn Problem Based Learning (PBL) pedagogy. They used the pedagogy to assemble students in interdisciplinary teams. The students then conducted their research inside and outside the classroom and presented their analysis and solutions. At the end of the course, the group of faculty and students traveled to London to experience the culture and technology first hand. Their travel was partially funded by the grant ${ }^{[4]}$. 
Problem Based Learning pedagogy is very well suited for honors students. In PBL, students bring resources to the classroom to share with their teams; they identify problems and issues and focus on the information they have to solve them. Faculty members act as moderators /advisors to keep the students focused and direct them to needed resources to solve the problems. Project Based learning using Problem Based Learning technique assign even more responsibility to Honors students. The students decide on a research methodology, plan the development of the project, divide the project to series of problems, solve the problems, and assemble the solution of the problems into the project for successful completion. The tasks that each student pursues depend highly on the project and on the student's background. The faculty advisors in the class coach the students to assume responsibilities for tasks that contribute most to the team. In "Historical London through the Lens of Technology" class for example, one Problem Based Learning asked the students to design a new transport museum for the city of London. Various students assumed different roles in their teams depending on their talents and background. One Industrial Design student from College of Design Art and Architecture designed a toy train for the tunnel (tube) that run along the transport museum, and built a virtual model to emulate the train. Meanwhile, a Construction Management student from College of Applied Science studied the history of construction of the tube and methods of excavation, and then created a continuous slide show depicting this history; one Architectural Engineering Technology student designed a floor plan and drew schematics for the museum. In the same team, one Information Technology student designed a computer simulation that demonstrates a ride on the Tube and a short visit to the museum. Finally, an English major student from College of Art and Science, unrestricted by all the knowledge of technology, headed up the brainstorming and research, and focused on the report and presentation efforts to deliver the project in a formidable presentation. The course taught the students how to work in interdisciplinary teams, conduct research and solve problems related to the interrelationships between the Technology and Society. They analyzed problems that the faculty prepared for them about the development of the city of London through the history ${ }^{4]}$.

The faculty involved in the course learned in a practical manner how to apply Problem Based Learning in the class. In addition, they presented several scholarly papers about Problem Based Learning and applied it to several courses that they teach.

In another Honors Special Topics course: "Leadership and Teamwork from Within", two faculty collaborated on providing various speakers for the course and in designing assignment related to experiential community service with Junior Achievement. They also participated with the students in a leadership camp that develop their leadership and teamwork skills. The course helped the students in learning about acquiring leadership skills and working in teams ${ }^{[5]}$. It generated materials for the faculty to coauthor a scholarly publication, and assembled information for a required course from Architectural Engineering Technology and Construction Management students on "Leadership and Strategic Planning." 
It is worthy to mention, that the Dean of College of Applied Science, a Physicist, proposed and taught a Special Topics Course on "Home Systems". He indicated that although the development of the course was time consuming, his experience was rewarding and challenging.

\section{Contract Honors Courses}

Technology students in the College of Applied Science obtain most of their honors credits by contracting required courses to be designated as honors courses. During the course, the students ask the faculty to mentor them for an enriching experience to qualify the course for Honors credits. In an Honors contract course, the student, with the guidance of the faculty, develops a proposal that is submitted on-line to the Honors office. The proposal is then sent back to the faculty for approval. Once approved, the proposal becomes a binding contract for honors credits. The student develops the required work to fulfill the contract and, upon successful completion of the proposal, earns the credit. There is no penalty for not completing the contract except that the student does not receive the credit. Several College faculty published papers, describing example of honors contracts ${ }^{[2][6][7]}$.

Honors contracts not only stimulate the students but also the faculty. Many times, the contract results in a publication for faculty and students. In one of the contracts between an Honors student and the author: "Improving Productivity in Construction Project", the student's report was sent to a national essay competition for Associated Builders and Contractors (ABC). The student won the competition, and went to Hawaii to present the paper to industry professionals, faculty and students attending the annual ABC competition in Honolulu in 2004.

In one class "Learning across the Disciplines" for Honors freshmen in the technology programs, three Honors students contracted the class for Honors credits. They attended weekly seminars to learn the development of electronic portfolios. They then, started the development of their own electronic portfolio for learning, assessment and marketing ${ }^{[9] \text {, }}$ [10], and [11]. Once the portfolio was completed, they helped the faculty in teaching the rest of the freshmen the development of portfolios.

In the College of Applied Science, many faculty reported significant synergy in classroom that include Honors students involved in Honors contracts. Honors students seem to feel more comfortable and challenged in their settings. They actively participate in the class and stimulate other students to do the same ${ }^{[7]}$.

\section{Independent Study Courses and Honors Experience}

In the Technology Programs at CAS, every department has a special course designated as Honors Independent Study course. Honors students can register to specially created sections taught by any faculty member to conduct independent studies and obtain honors credits. In one Independent study course students from Information technology program and Construction Management program, collaborated on an interdisciplinary project with 
faculty members from both disciplines. The substance of the project was to implement a web-based knowledgebase to help one construction company to transfer knowledge from experienced professionals in the field to newly hired professionals. The application allowed Messer Construction Company to develop an application to tap the experience of professionals for internal use of the company ${ }^{[8]}$. The project resulted in a grant from the company that started a scholarship endowment for the program in the college.

In another instance, the Honors Independent Study course was used by two students, one senior classman and one junior classman in Construction Management. The students developed a substantially complete electronic portfolio that reflected on their entire college career. The portfolios reflected on their cooperative work experience and on several course sequences in their coursework ${ }^{[12][13]}$. The electronic portfolio development was part of a study undertaken by several faculty members for implementing e-portfolios for all technology programs in the college.

\section{Honors Cooperative Experience}

This option for earning Honors credits is relatively new, and has not been yet used by technology students. It is created to enrich the cooperative experience of the students during their coop. At University of Cincinnati, technology students are required to gain a cooperative work experience every other Quarter after their first year and before their senior year. During the coop Quarters, the honors student discusses with his direct supervisor a work experience that entitles him or her to earn honors credit. Once the experience is identified, and approved by the employer, the student can register for a course entitled Honors Cooperative Work Experience with one faculty advisor. The work is jointly supervised by the faculty advisor from the technology program and the coop supervisor of the student. This honors experience, not only allows the student to earn Honors credit, but also encourages the employer to give the students challenging assignments that qualify the experience as honors experience.

\section{Conclusion}

The influence of University Honors Scholars program in the College of Applied has been very positive. The program stimulated honors students to seek out their potential in the technology programs. It has influenced classroom performance of all the students as well. There is no question as to the role of Honors program in providing needed opportunities to Honors students. In one survey conducted by a faculty in the college, the main motivation for Honors student to join the Honors program is to do more interesting and challenging work and gain additional interdisciplinary experience and knowledge. The initial concern was the added required work to earn "With Honors" designation. This concern quickly disappeared as they actively engaged with other students in completing their Honors experience ${ }^{[2]}$.

The Honors program stimulated many faculty members as they suddenly uncovered valuable resources in honors students. The students helped them to conduct research, to improve their teaching skills and to engage in scholarly work. In the last two years of the 
program, the technology faculty have authored or co-authored over 10 publications from their work with Honors students or other faculty. They taught over ten Honors Special Tropics courses and engaged in three multidisciplinary courses and experiences. In two instances, faculty members from six or more disciplines were involved in these courses, creating an atmosphere of collaboration. Many faculty members involved in the Honors program are untenured faculty. The scholarly work and the training to apply new teaching pedagogies are of utmost importance to them and to the programs. In summary, in the absence of graduate programs, University Honors Scholars program has provided valuable resources to the faculty and valued education to students in the College of Applied Science at University of Cincinnati

\section{Bibliographie}

[1] http:// www.honors.uc.edu/index.html

[2] Ossman Kathleen "Enhancing the Education of Engineering Technology Students through an Honors Program" Proceedings for the American Society of Engineering Education, Annual Conference and Exposition, Portland, OR. June 2005

[3] Fuller D “UC's Brightest New Students Take Up Hammers And Nails To Connect To Community, a lesson that combines books, construction and compassion". University of Cincinnati Press, http://www.uc.edu/news/NR.asp?id=1924 1994

[4] Inglert E, Ossman K, "Historical London through the Lens of Technology, A Facilitative Learning Approach as Authentic Alternative for Teaching the History of Technology" Proceedings for the American Society of Engineering Education, Annual Conference and Exposition, Portland, OR. June 2005

[5] Suckarieh George, Krupar Jason, "Leadership and Teamwork Education for Engineering and Technology Students, An Experiential Learning and Community Service Approach" Proceedings for the American Society of Engineering Education, Annual Conference and Exposition, Portland, OR. June 2005

[6] Rabiee Max, "Student Project in PLC Networking" Proceedings for the American Society of Engineering Education, Annual Conference and Exposition, Portland, OR. June 2005

[7] Gargari Mousa, "Students as Change Agents in Classroom" Proceedings for the Inter American for Engineering and Technology Education (Intertech), Annual Conference in Miami, FL. June 2005

[8] Suckarieh George, Prabhakar Annu, Walker Tim, , "Implementing a Web-Based Knowledge Base for a construction company: Proceedings for the American Society of Engineering Education, Annual Conference and Exposition, Salt Lake City, UT. June 2004

[9] http://homepages.uc.edu/ zimmermy/portfolio/index.htm

[10] http://homepages.uc.edu/ wallisaj/portfolio/index.htm

[11] http://homepages.uc.edu/ oharewj/portfolio/index.htm.htm

[12] http://homepages.uc.edu/ collinln/portfolio/index.htm

[13] http://homepages.uc.edu/ padgetmd/mikepadgettportfolio2/Portfolio.htm. 


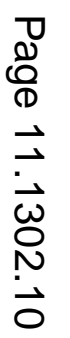

